
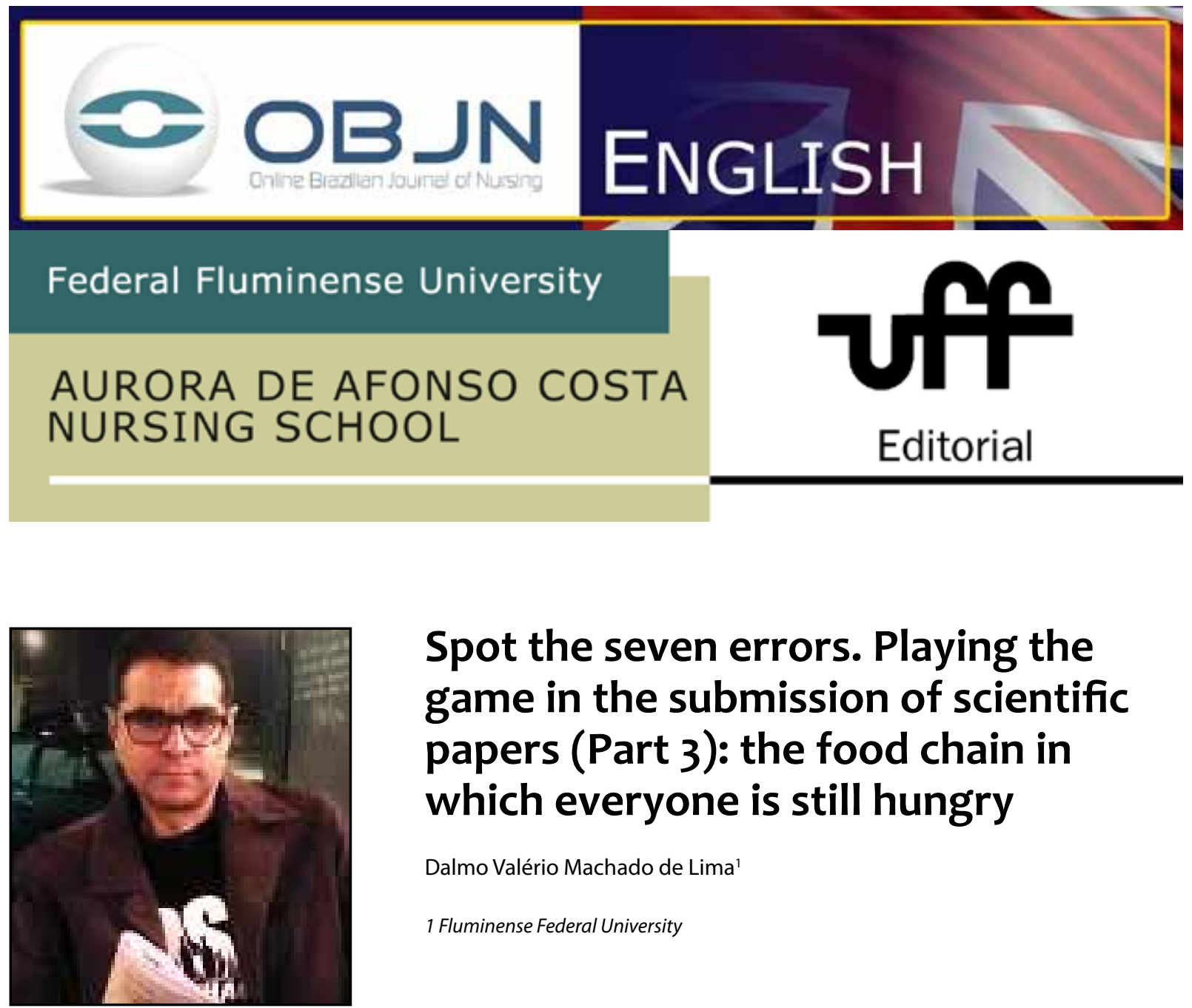

\title{
Spot the seven errors. Playing the game in the submission of scientific papers (Part 3): the food chain in which everyone is still hungry
}

Dalmo Valério Machado de Lima'

1 Fluminense Federal University

\section{ABSTRACT}

Since ancient times, especially from the sixteenth century, the effectiveness of relationships in any knowledge area has always been guided by productivity indicators. The health service therefore does not constitute an exception. And so, publications in health reflect the core of studies that originated them. Nursing, as a recent profession, still lacks a proper measurement model, since it is strongly influenced by the biomedical standard. Nevertheless, it is unquestionable the numerical increment of nursing publications worldwide. However, this quantitative progress is not proportional to the quality of publications; maybe due to the aforementioned biomedical model of hierarchical organization of studies, or maybe due to the eminently descriptive characteristic of their findings. Thus, the nursing area lacks intervention-type research that provide a real measurement of the effects of actions of nurses.

Descriptors: Publication Formats; Access to Information; Evidence-Based Nursing. 
Since ancient times, especially from the sixteenth century, the effectiveness of relationships in any knowledge area has always been guided by productivity indicators. The health service therefore does not constitute an exception. And so, publications in health reflect the core of studies that originated them.

Nursing, as a recent profession, still lacks a proper measurement model, since it is strongly influenced by the biomedical standard. Nevertheless, it is unquestionable the numerical increment of nursing publications worldwide ${ }^{(1)}$. However, this quantitative progress is not proportional to the quality of publications; maybe due to the aforementioned biomedical model of hierarchical organization of studies, or maybe due to the eminently descriptive characteristic of their findings ${ }^{(2)}$. Thus, the nursing area lacks intervention-type research that provide a real measurement of the effects of actions of nurses.

On the other hand, the Coordination for Improvement of Higher Education Personnel (CA$P E S$ ) in Brazil and related international agencies evaluate their own postgraduate courses based on derivatives of the strictu sensu programs, especially with regard to the triad: advisor, student and researched object. Although other factors are considered, the frequency and quantity of publications resulting from this triad is really relevant. However, a poor qualitative analysis of these has already been noted.

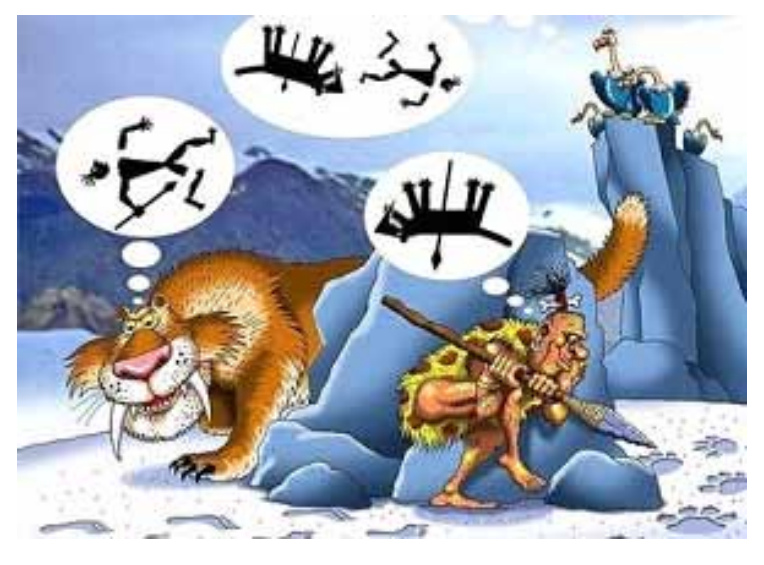

This modus operandi establishes a real "food chain" with adverse effects on the quality of published material. The chain begins by the regulatory institution of the postgraduate programs pressing the coordinators regarding the triennial production metrics. These, in turn, push the guiding teachers, who invariably push their mentees. And this creates loopholes that sometimes go so far as to undermine the primary function of post-graduate studies: to create and develop critical and reflective thinking in order to train researchers ${ }^{(3)}$.

Of these untimely "strategies" of article production line, the salami science was already discussed in a previous editorial(4), and also the logic of each discipline, an article, among others. It should be noted that during the master's and doctoral courses, many disciplines have few meetings, and others are essentially virtual. Therefore, it is counterproductive qualitatively from five or six meetings to conceive, gestate and give birth to a quality publication.

Issues that arise subsequent to that production line of articles are: Why so many garbage is published? Is it good if it was published? Do we live in an evidence-based illiteracy ${ }^{(5)}$ ? Do the impact factor, SClmago $\mathrm{H}$ index and the stratification of journal in Capes Qualis guarantee the quality of the manuscript?

And what are the things in common in these fast reports that have no time to project design, approval by an ethics committee, data analysis and manuscript preparation? The answer is, almost invariably, studies poor reviewed, skewed, with no possibility of replication, and which will face serious difficulties of acceptance in journals that can effectively score for the author, for the program and especially for the research consumers.

So, at the end of this food chain comes the melancholic conclusion that while everybody ate, nobody got fed indeed. And to the potential 
researchers remain the setback of having their first job after entering the course, deprecated. Therefore, the recommendation of this editorial is to produce less, but write better. Secondary nature research and reviews of any kind are studies of high evidence and as such cannot be trivialized because of this perverse production matrix, at the risk of finding no place for publication, a phenomenon already seen with relative frequency. However, the details about the review studies are the subject to the next editorial.

\section{REFERENCES}

1. CAPES (Brasil). Documento de área 2013. Brasília: Ministério da Educação; 2013. [cited xx xx xx] Available from: http://www.capes.gov. $\mathrm{br} /$ images/stories/download/avaliacaotrienal/ Docs_de_area/Enfermagem_doc_area_e_ comiss\%C3\%A3o_att08deoutubro.pdf

2. Social determinants for nursing [editorial]. Online braz j nurs 2011; 10(3): [about 4 p.]
3. Ministério da Educação (Brasil). Parecer n 977/65, de 3 de dezembro de 1965. Definição dos cursos de Pós-Graduação. Diário Oficial [da] União 3 dez 1965; Seção 1. Available from: http://www.capes. gov.br/images/stories/download/legislacao/ Parecer_CESU_977_1965.pdf

4. Paiva ED. Spot the seven errors. Playing the game in the submission of scientific papers (Part 2): the 'salami science' phenomenon. Online braz j nurs [internet]. 2014 June [cited 2014 Sept 22]; 13 (2): 125-8. Available from: http://www.objnursing.uff. br/index.php/nursing/article/view/4727.

5. O'Donnell M. Evidence-based illiteracy: time to rescue "the literature". Lancet. $2000 \mathrm{Feb}$ 5;355(9202):489-91.

Picture reference:

Ah, piá sabido [ilustração]. [s.l.]; [s.d.].

Received: 04/29/2014

Revised: 09/22/2014

Approved: 09/23/2014 